\title{
THE MUSEUM BRAZIL: CULTURAL CANNIBALISM AS AN ANSWER TO THE PREDICAMENTS OF A SHAKESPEAREAN CULTURE ${ }^{1}$
}

\section{O MUSEU BRASIL: O CANIBALISMO CULTURAL COMO RESPOSTA AOS DILEMAS DE UMA CULTURA SHAKESPEARIANA}

\author{
João Cezar de Castro Rocha ${ }^{2}$
}

\begin{abstract}
Resumo: Culturas shakesperianas são aquelas cuja autodefinição se baseia fortemente no olhar do estrangeiro, originando sua autopercepção pelo olhar do Outro. Então, nesta circunstância, a centralidade do outro implica a proeminência do impulso mimético na formação da identidade nacional, o que não pode deixar de evocar uma constelação paradoxal, baseada em uma constante oscilação entre o próprio e o estrangeiro.
\end{abstract}

Palavras-chave: canibalismo cultural; culturas shakesperianas

\begin{abstract}
Shakespearean cultures are the ones whose self-definition heavily relies on the determination of a foreigner's gaze, their self-perception originates in the gaze of an Other. Thus, in such circumstance, the centrality of the other demands the prominence of the mimetic impulse in the shaping of national identity, which cannot but evoke a paradoxical constellation, based upon a constant oscillation between the own and the foreigner.
\end{abstract}

Keywords: Cultural Cannibalism; Shakespearean Cultures

\section{A Country Museum?}

Shakespearean cultures are the ones whose self-definition heavily relies on the determination of a foreigner's gaze, their self-perception originates in the gaze of an Other. ${ }^{3}$ Thus, in such circumstance, the centrality of the other demands the prominence of the mimetic impulse in the shaping of national identity, which cannot but evoke a paradoxical constellation, based upon a constant oscillation between the own and the foreigner.

For a start, Latin American cultures emerged in the shadow of the Other - an (almost) absolute model. Its hegemony was never questioned; on the contrary, it passed itself off as second nature, a form of artificial respiration that became the skin we live in. The secondarity of the non-hegemonic condition, from this angle, "naturally" corresponds to the primacy of the Other - a European Other in the nineteenth century, North American in the next. In both cases, all one desires is to "be constantly up to speed on the latest news about the Other," is cast as unequivocally superior.

\footnotetext{
${ }^{1}$ This text is the result of a lecture delivered at the Colloquium "Grand Expositions," at Yale University. The oral tone of the lecture was kept.

${ }^{2}$ Universidade do Estado do Rio de Janeiro - UERJ, Rio de Janeiro, Rio de Janeiro, Brasil; https://orcid.org/0000-0001-5053-6768; jccr123@yahoo.com.br

${ }^{3}$ See João Cezar de Castro Rocha, Shakespearean Cultures. Latin America and the Challenges of Mimesis in Non-Hegemonic Circumstances. East Lansing: Michigan State University Press, 2019.

${ }^{4}$ In the words of the Mexican philosopher Carlos Pereda: "for the colonized, there is only the Other (this is true for us, especially if that Other speaks English, French, or German). That is why part of the arrogance of the colonized is to be constantly up to speed on the latest news about the Other. Inversely, for the colonizer there is no other: there is only Him, only Him. This is the arrogance of the colonizer." Juan Manuel Escamilla, "Filosofía
} 
As if cultural hegemony were a part of nature itself.

We should tread carefully to avoid misunderstandings. Take the intellectual atmosphere of the nineteenth century. Back then, the Other spoke the language of Voltaire, and the "arrogance of the colonized" led many to learn a French so perfect that it tickled Parisians. So it was that, with no apparent discomfort - deep down, with irrepressible pride - Joaquim Nabuco, a prominent Brazilian intellectual and leader of the Abolitionist movement in the nineteenth century, felt most at ease writing in French with Portuguese words: "indeed, I will be revealing no great secret if I say that my words are a free translation, and that nothing would be easier than to restore them to the French from which they derive (Nabuco, 1999, p. 66-67)." Given the ubiquity of this phenomenon, we should hardly raise an eyebrow upon coming across a similar formulation in the memoirs of the Argentinean writer Enrique Larreta. Having recognized France as his intellectual homeland, he capped off his line of reasoning with enviable coherence:

It's hardly extraordinary, then, that my literary expression, despite its musty flavor and purist ambitions, is not precisely that of a Spaniard from Spain, and that should occasionally reveal in its internal structure, its syntactical structure, the influence of writers of that other nation. For my part, I have always recognized it.

(Larreta, 1947, p. 70)

"That other nation" was the absolute Other. The asymmetrical relationship is a one-way street: the secondarity of the non-hegemonic condition determines the primacy of that Other. In this article, I will deal with the challenges implied in such oscillation between the Self and the Other through the presentation of the theory of cultural cannibalism or anthropophagy, as it was developed in Brazil in the 1920s in the context of the avant-garde movements.

Slavenka Drakulic's novel The Taste of a Man offers a privileged vantage point to seize the predicaments of Shakespearean cultures and at the same time it refers keenly to Brazilian cultural history. In Drakulic's novel, Tereza, a young Polish poet studying literature in New York, meets José, a Brazilian anthropologist from São Paulo who is conducting research for a future book, which indeed is never going to be written. They first met at the New York Public Library. The book José was consulting attracted Tereza: Divine Hunger, a classic study on cannibalism by Peggy Sanday. ${ }^{5}$ Next time, they casually went to the same exhibition, held at the Library: "From Portugal to Brazil: The Age of Atlantic Discovery." Predictably enough Tereza will be especially interested by a 1505 woodcut by Johann Froschauer in which native Indians are shown dismembering a human body that is soon to be eaten. Suddenly she is struck by a revelation:

Exhibited in a glass case was a copy of Pero Vaz de Caminho's (sic) letter to King Manuel, written on 1 May 1500. 'They were dark and completely naked, with nothing to cover their shame. They all moved boldly toward the ship and Nicolau Coelho (...) could not exchange a single word with them, or understand them.' The killing by both sides, the attempts at extermination, went on for a long time, but in the end they did intermix. I wondered whether José felt these two conflicting currents flowing and clashing inside him, like two streams of blood. (Drakulic, 1998, p. 26-27)

en Primera, en Segunda y en Tercera Persona: Entrevista a Carlos Pereda,” Open Insight 3, no. 4 (2012): 150 (italics mine).

${ }^{5}$ Peggy Reeves Sanday. Divine Hunger. Cannibalism as a Cultural System. Cambridge: Cambridge University Press, 1986. 
I'll return to Drakulic's novel, but I should now suggest a different approach to Pero Vaz de Caminha's Letter (Carta do Achamento do Brasil) concerning the arrival of the Portuguese in the new world.

\section{The Letter}

Pero Vaz de Caminha was probably born around 1450 in the city of Porto. He was one of the official writers to the King of Portugal, and in this quality, he joined Pedro Álvares Cabral's expedition that landed in the territory that later would become Brazil. Caminha wrote his report to King Manuel between April 22 and May 1, 1500. The Letter constitutes a vivid description of the first colonial encounter in that part of the New World.

Naturally, I will not propose in this article a detailed interpretation of Caminha's Letter. Rather I want to stress one aspect of it intrinsically related to my argument. It is important to acknowledge that Caminha's Letter was only reproduced and therefore known in the nineteenth century, more precisely in a long footnote in Aires de Casal's Corografia brasílica, published in1817. Nonetheless, I'm mainly concerned with the characterization of the colonial project through a specific reading of the Letter. In that sense, it remains a fundamental text in spite of its late diffusion. Hans Ulrich Gumbrecht and Memory Holloway have insightfully remarked upon the uniqueness of Caminha's style.

Gumbrecht defined it through the "text's historical immediacy." Caminha employs the present tense and also informs the reader of the circumstances of the writing itself. Sometimes the Letter reminds us of a diary, for Caminha punctuates it with observations such as: "on this day, there was nothing more that deserved to be mentioned". ${ }^{7}$ He even concludes it with the here-and-now style that since 1500 seems to conquer the reader's imagination: "I kiss the hands of Your Highness. From Porto Seguro, from your Island of Vera Cruz, today, Friday, the first day of May of $1500 " .8$

Holloway has added an important feature to Caminha's style, according to which the Portuguese writer, "carefully observed what he saw and described it with accuracy," instead of automatically following the genre of discovery narrative, which usually depicted native populations as hybrid and monstrous creatures, therefore, as inhuman in appearance. The very word cannibalism was coined in such a context. Therefore, it is worth briefly recalling its creation.

The entry for 23 November 1492 in Columbus's Logbook started the circulation of the word in European discourse. It comes from the Arawak caniba, a corruption of cariba, which means "bold." That was the word used by the Indians of Lesser Antilles to describe themselves, since they were warriors. However, the Arawak people used it rather to express the fear they felt of their neighbors, meaning that the "bold" were above all to be feared because of their violent attacks.

Columbus not only adopted the Arawak meaning of the term, but with it anticipated the operation that defines the colonial project. Columbus associated the word "Khan-iba" with the

\footnotetext{
${ }^{6}$ Hans Ulrich Gumbrecht. "Who was Pero Vaz de Caminha?” João Cezar de Castro Rocha (Ed.). Brazil 2001: A Revisionary History of Brazilian Literature and Culture. Dartmouth, MA: Center for Portuguese Studies and Culture, 2001, p. 424.

7 “(...) e asy nõ foy mais este dia que pera screpuer seja." J. F. de Almeida Prado and Maria Beatriz Nizza da Silva (Eds.). Pero Vaz de Caminha. Carta do achamento do Brasil. Rio de Janeiro: Agir, 1998, p. 144, my emphasis.

8 "Beijo as maãos de vosa alteza. Deste porto seguro da vossa jlha de vera cruz oje sesta feira primeiro dia de mayo de 1500." Idem, p. 151.

${ }^{9}$ Memory Holloway. "Praying in the Sand: Paula Rego and Visual Representations of the First Mass in Brazil." João Cezar de Castro Rocha (Ed.). Brazil 2001: A Revisionary History of Brazilian Literature and Culture. Dartmouth, MA: Center for Portuguese Studies and Culture, 2001, p. 698.
} 
Great Khan of the Mongols. After all, Columbus was convinced he had arrived in India - which explains why he called the Natives, Indians, inaugurating a long tradition of cultural misreadings. Moreover, in Italian, "Il Gran Cane" allowed for an involuntary pun, meaning both "The Great Kahn" and "The Great Dog". Finally, the classical author Pliny had described the population of the fringes of the world as man-eating dog-headed tribes. Columbus mixed all those elements to conclude that the Caribbean Indians that he had not yet met were maneaters. On 11 December 1492 he writes in his Journal:

I therefore repeat what I have said several times: that the Caniba are none other than the people of the Great Khan (...). They have ships, they come and capture [the Arawks], and as those who are taken never return, the others believe that they have been eaten. ${ }^{10}$

On the contrary, Caminha seems to really be impressed by the newness of the first encounter between Portuguese men and native Indians and, although he clearly obeys the laws of the genre of the discovery narrative, nonetheless, and that is my contention, his descriptive prose inaugurates what I would like to call the rhetoric of "Brazil as exposition," a supplement to the image of "the Museum Brazil."

On the one hand, this rhetoric implies a visual style. It is as if Caminha writes not on paper but on a canvas. It is as if he is more concerned with fixing images than combining words. We could easily imagine Caminha translating his prose into a collection of drawings and watercolors - as Jean-Baptiste Debret will do while in Rio de Janeiro in the nineteenth century. Therefore, it is not surprising to learn that the concreteness of Caminha's style inspired one of the most emblematic images of Brazilian cultural history: the representation of the First Mass in Brazil, by Victor Meirelles, painted in 1860. His oil on canvas, dutifully titled The First Mass in Brazil, is perhaps the most widely reproduced image of a painting in Brazil, and has inspired artists as diverse as the Brazilian naïve artist Lia Mittarakis in her 1980 The First Mass in Brazil on April 26, 1500, as well as the Portuguese artist Paula Rego in her 1993 First Mass in Brazil.

On the other hand, the rhetoric of "the Museum Brazil" also implies the objectification of the land. In Caminha's Letter, the landscape and its potentials resources, the population and its features are depicted as objects in a sort of "Natural Museum," as if they were being displayed at an exhibition whose curator is, paradoxically, the beholder himself. Let me immediately add that the beholder has primarily been throughout Brazilian cultural history a foreigner whose authority is derived from his condition of being a foreigner. It is a tautological mechanism that is still active today.

Later on, objects will keep on having the unusual status of embodying the land. Its own name, Brazil, was derived from the commodity with which the land was inscribed into the colonial system: brazil-wood (pau-brasil). Thus, the etymology of Brazilian is anything but noble; it simply refers to the merchants of brazil-wood. Rather than a national definition, "being" Brazilian implied a professional identity. Brazilian was the one who profited from trading goods of the land by taking advantage of the native populations. As Roland Greene has remarked, "the drama of the objectification is the unfolding story of how objects such as paubrasil come to be invested with meaning, how those objects are seen to embody the place Brazil."11

\footnotetext{
${ }^{10}$ Christopher Columbus. Textos y documentos completos. Relaciones de viajes, cartas y memoriales. Consuelo Varela, ed., prólogo y notas. Madrid: Alianza, 1982, p. 78. [“...que Cariba no es otra cosa sino la gente del Gran Can, que deve ser aquí muy vezino; y terná navios y vernán a captivarlos, y como no buelven, creen que se lo (han) comido.']

${ }^{11}$ Roland Greene. “Anthropophagy, Invention, and the Objectification of Brazil.” João Cezar de Castro Rocha and Jorge Ruffinelli (Eds.). Anthropophagy Today? Stanford University, 2000, p. 116. For a fuller discussion of this topic, see his book Unrequited Conquests. Love and Empire in the Colonial America. Chicago: The
} 
Objects can become the embodiment of the land because autonomy is denied to its native populations. After all, it was the arrival of the Portuguese that inscribed both the land and the population into "history." Therefore, already in its first formulation, the rhetoric of "the Museum Brazil" was grounded on the most basic premise of the colonial project, according to which colonies were but a collection of objects to be exploited. In other words, and in spite of the freshness of Caminha's perception, the "Natural Museum" that emerges from his Letter is more than a metaphor. Indeed, it anticipated the centuries to come, since the colonial subject can never be fully regarded as subject.

\section{Romanticism}

The artists, writers and men of letters who helped to shape Brazilian Romanticism could not accept this assumption. Romanticism itself is the affirmation of subjectivities, be it the genius of an individual creator, be it the collective spirit of a given people. Moreover, in 1822 Brazil became an independent country, and the beginnings of Romanticism, officially dated 1836 with the publication of Suspiros poéticos e saudades by Gonçalves de Magalhães, were seen as the promise of a literary threshold. Therefore, in order to become possible, Romanticism in Brazil had to overcome the colonial model of "the Museum Brazil."

This overcoming of the colonial model was attempted through its inversion. Instead of accepting the mere role of objects to someone else's exhibition, the Romantic generations took to themselves the responsibility of narrating the nation according to their own perspective. The creation of the Instituto Histórico e Geográfico Brasileiro, in 1838, was meant to provide institutional support in order to accomplish this mission. As early as 1839 the Institute began to sponsor the publication of a Journal whose aim was to give visibility to the work of its members. It was in the pages of the Journal of the Institute as well as in the novels of the Romantic authors that the colonial model of "the Museum Brazil" changed into the project of the "the Exposition of Brazil."

In that sense, the Journal of the Instituto Histórico e Geográfico Brasileiro is as important and symptomatic as Caminha's Letter. In its pages, the reader was introduced to maps of almost unknown regions of the country recently declared independent; reports on surviving native populations; biographies of distinguished fellow countrymen; documents related to the colonial period; chronicles of episodes of the country's history. ${ }^{12}$ The Journal became a sort of "Printed Museum" of the history of Brazil. The collection of data was impressive and, at the same time, literary Romanticism was searching for a form through which Brazil's identity could be expressed. In that context, the writing of the history of Brazil would correspond to the undisputed affirmation of one's own subjectivity.

It is not surprising, therefore, that in 1840 the Instituto Histórico e Geográfico Brasileiro launched an international competition, offering a relevant award for the scholar who would present the best plan to write the history of Brazil. The German naturalist Karl Friedrich von Martius won the prize with an essay titled "How the History of Brazil should be written," properly published in the Journal of the Instituto Histórico e Geográfico Brasileiro in 1845. According to Martius, an epic adventure took place in the Brazilian territory during the colonial period. In order to understand the nature of the country's civilization, the historian's task was to explain the nature of that epic. Indeed, in Martius's view, the history of Brazil is but "the perfection of the three human races that are located side by side in this country in a way

\footnotetext{
University of Chicago Press, 1999; especially chapter 2, “ 'For Love of Pau-Brasil': Objectification in Colonial Brazil", pp. 77-134.

${ }^{12}$ For an account of the history of the "Instituto," see Lúcia Maria Paschoal Guimarães. Debaixo da imediata proteção imperial: O Instituto Histórico e Geográfico Brasileiro (1838-1889). Revista do IHGB, ano 156, no. 388, 1995.
}

Rev. Bras. Lit. Comp. Niterói, v. 22, n. 41, pp. 15-26, set. /dez. 2020 
unknown in ancient History." ${ }^{13}$ Nonetheless, a clear hierarchy had to be established: "we will never be allowed to doubt that the will of Providence destined this mixture to Brazil. Portuguese blood, in a powerful river, should absorb the small tributaries of the native and African races." 14 The words of the young Polish poet of Drakulic's novel seem to echo Martius's project, for in spite of all killings and attempts at extermination "they did intermix," as the novelist put it.

Of course, I will not dwell on Martius's essay, although it has powerfully influenced the writing of Brazilian history and the understanding of its culture. After all, from José de Alencar's Iracema (1865) to Gilberto Freyre's Casa-grande \& senzala (1933), miscegenation is seen as the key to Brazil's origins and originality. The point I want to make through Martius's essay, however, is that the Romantic project was haunted by an inner contradiction: it aimed at transforming Brazilians into subjects of their own history. The "Exposition of Brazil" should result in the "subjectification" of Brazilians. Brazil would exist as long as Brazilians knew how to narrate it: that would have been the Romantic's answer to the challenge faced by Shakespearean cultures.

Nonetheless, like typical Shakespearean characters who usually fall in love through the eyes of someone else, it seemed that Brazilians learned to recognize themselves primarily through the authority attributed to a foreigner's gaze. If Martius taught us the origins of our historical originality, Ferdinand Denis, as studied by Maria Helena Rouanet, gave us the recipe for a Romantic literature in the tropics. ${ }^{15}$ Predictably enough, it should not focus on psychological exploration of subjectivities, a task already fully accomplished in Europe, as we are supposed to believe. In order to occupy an alternative niche in the vast panel of "World Literature," the writers of the newly independent country should specialize in the description of its overwhelming nature and landscapes. As early as 1816 Brazilians had already welcomed the so-called French Artistic Mission that arrived in order to learn how to represent visually the land and themselves. Headed by the writer Joachim Lebreton, the French Artistic Mission arrived in Brazil on 26 March 1816, bringing landscape as well as historical painters, sculptors, and architects with a two-fold civilizing mission: on the one hand, making the city worthy of receiving the Portuguese Court that came to Brazil in 1808; on the other, establishing an Academy of Fine Arts.

In a nutshell, the project of the "Exposition of Brazil" could not completely overcome the model of "the Museum Brazil." In both cases, and in spite of remarkable differences, it is the beholder who is the actual curator of the exhibition, providing the guiding principle under which subjects are subsumed and objects are consumed.

\section{Anthropophagy}

Speaking of consumption, I should now offer the main course of this presentation: Oswald de Andrade's notion of anthropophagy, ${ }^{16}$ as it was proposed in the "Manifesto antropófago", first published in 1928, and fuller developed in his late writings of the $1950 \mathrm{~s} .{ }^{17}$

\footnotetext{
${ }^{13}$ Karl Friedrich von Martius. "Como se deve escrever a História do Brasil". O estado de direito entre os autóctones do Brasil. São Paulo: Editora da USP; Belo Horizonte: Livraria Editora Itatiaia, 1982, p. 89.

${ }^{14}$ Idem, p. 88.

${ }^{15}$ Maria Helena Rouanet. Eternamente em berço esplêndido. A fundação de uma literatura nacional. São Paulo: Siciliano, 1991.

${ }^{16}$ Oswald de Andrade. "Manifesto antropófago." A utopia antropofágica. São Paulo: Editora O Globo, 1990, p. 47. The "Manifesto" was launched in May 1928, in the first issue of the Revista de Antropofagia. The available English translation is "Cannibalist Manifesto," translated by Leslie Bary. Latin American Review 14.27 (1991): pp. 35-47. There is another translation by Alfred Mac Adam, AnthropophagistManifesto.” Review: Latin American Literature and Arts 51 Fall (1995): pp. 65-68.

${ }^{17}$ See especially A crise da filosofia messiânica. A utopia antropofágica. São Paulo: Editora O Globo, 1990, pp. 101-155.
} 
There is in the notion of anthropophagy something that met the challenge of both objectification and self-definition through a foreigner's perspective. These problems constitute the core of Oswald de Andrade's notion of anthropophagy, as well as the underlying force of Brazilian cultural history. Indeed, it can be said that Oswald's aim was to rewrite Pero Vaz de Caminha's Letter. Therefore, the origins of Brazilian history would not be dated 1500, but 1556, when the Bishop of Bahia, Pero Afonso de Sardinha, was killed. ${ }^{18}$ While navigating the São Francisco river, he was captured and murdered by the Aimorés, and according to legend the Bishop Sardinha (that is, Bishop "Sardine") was properly devoured in a tasty Aimore stew. The Bishop's name was a ready-made signifier that Oswald de Andrade readily incorporated into his own cultural project.

As a matter of fact, anthropophagy had already surfaced during Romanticism, but it was only within Modernism that it became a new approach to the understanding of Brazilian culture. The Tropicalist movement renewed the notion in the 1960's. In 1998, it provided the conceptual framework for the XXIV edition of the "Bienal de São Paulo." As the curator of the Biennial insightfully remarked: "Anthropophagy is sufficiently polemic a concept not to be branded as truth; not even as a means of explaining pictorial representations or styles. (...) The notion of anthropophagy, as a cultural strategy, as well as its links with cannibalism, has provided a dialogical model for interpretation, i.e., the anthropophagous banquet." ${ }^{19}$ Jorge Schwartz organized an impressive exhibition in Spain, "De la antropofagia a Brasilia", in which the notion of anthropophagy revealed itself as instrumental for the reconstruction of Brazilian cultural life from the 1920's to the late 1950's. ${ }^{20}$ Finally, Edward Sullivan, the curator of the overwhelming exposition shown at the Guggenheim Museum, "Brazil: Body and Soul," touched the heart of the matter:

Every paradise has its contradictions, and that of Brazil was cannibalism. Early writings of the country emphasized the many peculiar practices of the indigenous peoples, yet the custom that was most avidly remarked upon was the habit of eating other humans. While the extent of real instances of cannibalism is debatable, the metaphoric potential of the act laid the foundation for philosophical discussions about the Brazilian character throughout the twentieth century. ${ }^{21}$

How to account for this omnipresence of anthropophagy in Brazilian cultural history?

First of all, it should be remembered that the first descriptions of the territory that later would be called Brazil already highlighted the link between the New World and anthropophagous rituals. ${ }^{22}$ In the 1557 best-selling book by Hans Staden, better known as Two voyages to Brazil, this link is made explicit in the title itself, which literally devours the book's

\footnotetext{
${ }^{18}$ Jeffrey Scnhapp has shown a curious sleep in Oswald de Andrade's chronology: "But more fishy than the legend of Sardinha's end is the chronological slippage in the "Manifesto antropófago's conclusion. 1554 plus 374 equals 1928; 1556 plus 374 equals 1930; which is to say that Oswald, writing in early 1928, got it wrong." Jeffrey Schnapp, "Biting the Hand that Feeds You.” João Cezar de Castro Rocha and Jorge Ruffinelli (Eds.). Anthropophagy Today? Stanford University, 2000, pp. 244-245.

${ }^{19}$ Catálogo da XXIV Bienal de São Paulo. Núcleo histórico: Antropofagia e histórias da civilização. São Paulo: Fundação Bienal de São Paulo, 1998, p. 23.

${ }^{20}$ Jorge Schwartz. De la antropofagia a Brasilia: 1920-1950. Valencia: IVAM, 2000.

${ }^{21}$ Edward Sullivan. "Brazil: Body and Soul.” Brazil: Body and Soul. New York: Guggenheim Museum, 2001, pp. $2-3$.

${ }^{22}$ The theme of cannibalism in its links with the New World is already the focus of frequent discussion. It is worth mentioning the book edited by Francis Barker, Peter Hulme and Margaret Iversen, Cannibalism and the Colonial World. Cambridge: Cambridge University Press, 1998. In the Introduction, entitled "The Cannibal Scene", Hulme focuses on the problem from a wider perspective, but does not fail to mention Oswaldian anthropophagy, especially on pages 26-29. Also noteworthy in this volume are the essays by Sérgio Luiz Prado Bellei, "Brazilian Anthropophagy Revisited" (pp. 87-109) and by Luís Madureira, "Lapses in Taste: 'CannibalTropicalist' Cinema and the Brazilian Aesthetic of Underdevelopment” (pp. 110-125). Peter Hulme had already studied this topic. See Colonial Encounters. European and the Native Caribbean, 1492-1797. London \& New York: Routledge, 1986; especially the first chapter entitled "Columbus and the cannibals", pp. 13-43.
} 
cover: A truthful description of a land of naked, wild and man-eating savages, situated in the New World of America, unknown in Hessen, before and after the birth of Christ, until two years ago, Hans Staden from Homberg in Hessen, became personally acquainted with them and now, makes this experience public by means of this printed book. ${ }^{23}$ Similarly the reference to anthropophagy appears in the always-quoted essay by Montaigne, "Of Cannibals", in which the author reports his alleged encounter with natives captured on the Brazilian coast. ${ }^{24}$

In addition to texts, visual portrayals of that time also confirmed what the printed word suggested, by depicting Brazil as a large extension of land, whose coast was inhabited either by natives who collected brazil-wood for trading with Europeans or by those who collected Europeans in order to devour them in complex anthropophagous rituals. It is for these reasons that the "rediscoveries" of the theme in literature, cinema, music and the arts have strategically started from a double re-reading both of the notion of anthropophagy and of the reports by the European colonizers. Such is the case of the paradigmatic 1973 film by Nelson Pereira dos Santos, How Tasty was my Frenchman, which represents a critical approach to the chroniclers as well as the enactment of the anthropophagous ritual. As far as the repercussions of anthropophagy within Brazilian cinema is concerned, it is necessary to recall Macunaima, the 1969 film by Joaquim Pedro de Andrade, which is a rereading of Mário de Andrade's rhapsody. Joaquim Pedro's testimony is eloquent:

(...) anthropophagy is something which the underdeveloped understand. To think that I was shocked when I got to know that Godard's Weekend ended with a scene of a woman eating the remains of her husband and asking for seconds. I was then just finishing Macunaima. In Venice there were other films about cannibalism. Pasolini has also included the topic in one of his most recent films, Porcile. It is interesting that artists from both developed societies and our own have had the same idea at a certain stage in the careers. Anthropophagy is not a new idea in Brazil. However, I have taken too long to understand the political depth of Oswald de Andrade's ideas. ${ }^{25}$

Thus, anthropophagy was Oswald de Andrade's answer to the objectification of Brazilian culture by transforming European subjects into metaphorical objects of consumption. It is worth remembering that in 1924 he launched the "Manifesto da poesia pau-brasil," according to which "brazil-wood poetry" should be exported. ${ }^{26}$ However, it would not be a natural but a cultural commodity that was to be exported, suggesting that Brazil would only achieve autonomy through its culture, rather than through its natural resources, as it is

\footnotetext{
${ }^{2323}$ In the original: Die Wahrhaftige Geschichte und Beschreibung einer Landschaft der

Wilden, nackten, grimmingen Menschenfresser, in der Neuen Welt Amerika gelegen, vor und nach Christi Geburt im Lande Hessen unbekannt, bis auf die zwei letzvergangen Jahre, da sie Hans Staden von Homberg aus Hessen selbst kennengelernt hat und jetz durch den Druck bekannt macht.

${ }^{24}$ I have proposed an alternative interpretation to Montaigne's meeting with those Indians, see "Montaignes Kannibalen. Die Wilden Brasilien und die europäischen Religionskriege." Frankfurter Allgemeine Zeitung, Geisteswissenschaften N. 207, p. 5, 6 September 2000. For an insightful analysis of Montaigne's position in the historical context of the religious wars, see Carmen Nocentelli-Truet, "Léry, Montaigne, and Communal Identities in Sixteenth-Century France.” João Cezar de Castro Rocha and Jorge Ruffinelli (Eds.). Anthropophagy Today? Stanford University, 2000, pp. 93-114. Regarding a classical interpretation on the symbolic importance of the encounter with the natives of the New World to the European philosophy, see Afonso Arinos de Melo Franco. O índio brasileiro e a Revolução Francesa. As origens brasileiras da teoria da bondade natural. Rio de Janeiro: Topbooks, 2000. The first edition was published in 1937.

${ }^{25}$ Apud Heloisa Buarque de Hollanda. Macunaíma: da literatura ao cinema. Rio de Janeiro: José Olympio/Embrafilme, 1978, p. 112.

${ }^{26}$ The Manifesto da poesia Pau-Brasil was first published in the Correio da Manhã, on 18 March 1924. The only English translation is by Stella M. de Sá Rego. Latin American Review 14.27 (1986): pp. 184-187.
} 
commonly stated. Nonetheless, the full answer provided by Oswald demanded yet another dimension.

As I have already recalled, the Indian-oriented trend within Brazilian Romanticism had already strategically employed the notion of anthropophagy. It could not have been different, for Europeans condemned the anthropophagous ritual as being no more than barbaric, therefore justifying the colonial project itself. Modernist writers and artists, however, were the ones who really transformed anthropophagy into an intrinsically positive idea-force. They did so by reinterpreting the anthropophagous ritual, bestowing it with a dialectical dimension regarding the foreign element. This dialectical movement was especially needed because the European avant-gardes had furnished the initial model for Brazilian Modernism. In this way, anthropophagy helped to overcome the paradox of a movement whose aim was to rediscover Brazil, but whose premises were on the other shore of the Atlantic Ocean. The paradox resolved itself by means of the anthropophagous digestion of the values of the other, that is, the foreigner's. Thus, the Romantic dilemma would hopefully be left behind.

Highly influenced by Modernism, Tropicalism revived anthropophagy. The 1960's cultural movement related anthropophagy not only to an external element, but also to the dawn of mass culture set in the most important Brazilian urban centers in the 1950's and 1960's. Torquato Neto's writings, José Celso Martinez Correa's theater, Hélio Oiticica's and Lygia Clark's innovations in fine arts, Glauber Rocha's and Joaquim Pedro de Andrade's cinema, among many other artistic manifestations, sought to appropriate the notion of anthopophagy. Caetano Veloso summarized this impulse perfectly: "We, Brazilians, should not imitate, but rather devour new information, wherever it comes from (...). The idea of cultural cannibalism fitted our Tropicalist purpose like a glove. We were 'eating' both the Beatles and Jimi Hendrix."27

In Drakulic's novel, rather it is Tereza who has the upper hand. José, the Brazilian anthropologist who was researching to write a book on anthropophagy, decided to return to Brazil and resume life with his family. Then, Tereza resorts to what she understands as the ultimate gesture of love: she kills José and fully assimilates him into her body and soul through cannibalism. As she says at the end of the novel: "And he is here, inside me, enclosed forever in my body, in my every cell. He lives inside me. He touches my hands, breathes with my breath, sees through my eyes." 28 Indeed, that is what Brazilians have been doing throughout their cultural history; they have discovered themselves through the eyes of someone else especially when they naïvely believe themselves to be naturally anthropophagites.

For instance, let's take a look at a tourist guide titled Eating Brazil. The purpose of its authors is explicated through the exploitation of all nuances of the anthropophagic semantic field:

Eat Brazil. That is the credo of this book. Do not try to understand its culture, for that would be a little absurd. Do not try to comprehend its economy or to grasp its order, for that is hopeless. There is only way to go. Eat Brazil up. Consume its landscapes. Devour its cities. $^{29}$

\footnotetext{
${ }^{27}$ Caetano Veloso. Verdade tropical. São Paulo: Companhia das Letras, 1997, pp. 241-262; English translation, Tropical Truth. Isabel de Sena, trans. New York: Knopf, 2002.

${ }^{28}$ Slavenka Drakulic. The Taste of a Man. London: Abacus, 1998, p. 212.

${ }^{29}$ John Bosch, Juliette van der Meijden, Maurice Nio, Wim Nijenhuis, Nathalie de Vries. Eating Brazil. Roterdam: 010 Publishers, 1999, n/p.
} 
The authors even refer explicitly to Oswald de Andrade's notion of anthropophagy. ${ }^{30}$ The obvious commercial appeal of the anthropophagic metaphor could not be more clearly evinced. At the same time, it clarifies the naïveté of the process of self-exoticism through which some Brazilian intellectuals and artists present themselves abroad as "naturally" anthropophagites. This is exactly what is expected of them. In that context, it does not really matter if the effort is more sophisticated than a mere tourist guide.

I have in mind Christopher Pillitz's Brazil incarnate, an impressive collection of photographs, which carries a preface by Caetano Veloso and an essay by Paul Theroux. Whereas Veloso raises some doubts regarding the project itself, ${ }^{31}$ Theroux indulges in the most predictable clichés:

Traveling in Brazil, I realized there were many aspects of the country I had to accept or else I would go mad. (...) the body is an artifact. The instinct of these people is not commitment or introspection, but frankly to be sex objects, reeking with pheromones. It is perhaps the oldest instinct on earth. ${ }^{32}$

And as the photographer declares with no perceptible embarrassment, "Brazil is a country of uninhibited sensuality, devoid of taboos. Its chaos, its lawlessness and violence are inseparably related to its obsession with sex." 33 Seemingly, he does not realize that this treatment of the Brazilian body (whatever this level of generality might mean) reduces Brazilian culture to the mere role of being an object to foreigner's perception and desire - "sex objects," in the straightforward confession of Paul Theorux. Through the lenses of Pillitz, the body of Brazilians becomes the object, which embodies the country's soul, bringing to the utmost the drama of objectification referred to by Roland Greene.

Paulo Herkenhoff and Jorge Schwartz, on the contrary, not only deepened the gesture of cultural appropriation but also created conditions for overcoming a paradox that anthropophagy itself was not able to surpass. Nonetheless, it should be emphasized that the omnipresence of anthropophagy in Brazilian cultural history is related to the successful coping with the impasse of both objectification and self-definition through a foreigner's perspective. If Brazilians were cultural cannibals, then there would be a Brazil inhabited by hungry Brazilians, so to speak. In other words, the anthropophagous model would neither be "the Museum Brazil," nor "Exposition of Brazil." Rather, it would portray Brazilians as active consumers of both the foreigner's perspective and the contradictions of the country itself.

\section{Concluding remarks}

Since the contradiction of this optimistic anthropophagic self-portrait was already shown through the potential for an exotic appropriation of "naïve cannibals," I should be the

\footnotetext{
30 “Anthropophagy, abaporu, cannibalism. (...) The Portuguese once sent a Bishop to Brazil. The Indians made a tasty meal of him. In Manifesto antropófago (1928), Oswald de Andrade called on the Brazilian artists to devour everything that comes from abroad. European culture, in particular, must be digested and softened up until the Brazilian mould can be imposed on it. Abrasileirar ." Idem, pp. 41 \& 43.

31 "Brazilian sensuality is a difficult, 'touchy' subject for Brazilians to deal with. It is not merely the fear of a ridiculously involuntary narcissism, or simply foolish vanity. Our sensuality, when we discuss it with foreigners, creates in us considerable anxiety because it touches upon issues in the historical construction of our precarious self-respect." Caetano Veloso. "Brazilian Sensuality.” Christopher Pillitz. Brazil incarnate. London: Networks Photographers, 2000, n/p.

${ }^{32}$ Paul Theroux. "Brazil Incarnate.” Christopher Pillitz. Brazil incarnate. London: Networks Photographers, $2000, \mathrm{n} / \mathrm{p}$.

${ }^{33}$ Christopher Pillitz. Brazil incarnate. London: Networks Photographers, 2000, n/p.
} 
first to call into question my own exposition. To consider anthopophagy a "Brazilian" invention or the definition of Brazilian identity is a paradox that unfortunately has dominated the interpretation of Oswald's works. It is true that Oswald himself allowed for such understanding in his "Manifesto antropófago." When he returned to the idea of anthropophagy in the 1950s, however, he tried to review it within an anthropological framework, which necessarily goes beyond the rigid boundaries of the search for national identity. ${ }^{34}$

Oswald had fully intuited the anthropological dimension of anthropophagy as it is summarized by Peggy Sanday: "Cannibalism is never just about eating but is primarily a medium for nongustatory messages - messages having to do with the maintenance, regeneration, and, in some cases, the foundation of the cultural order." 35 Not only did Oswald open his Crise da filosofia messiannica (1950) with a remarkably similar distinction, ${ }^{36}$ but he also understood anthropophagy as a cultural system initially derived from the Tupi-guarani's historical experience,${ }^{37}$ and later universalized it as a key to compose an alternative history of mankind.

In other words, if anthropophagy is a cultural procedure that implies a continuous and productive assimilation of the other, of alterity, then, it also implies a permanent process of change and new incorporations. Such cultural procedure cannot provide the stability required by a national definition of identities, which tends to represent itself as fixed. Moreover, as a cultural procedure, anthropophagy is neither Brazilian nor Latin American. Rather, it can be better understood as follows: anthropophagy is a strategy employed in contexts of political, economic and cultural asymmetry by the ones that are located in a position of inferiority. Geographic borders cannot limit an anthropophagic strategy, since its aim is to precisely question those self-referential definitions, as Arthur Rimbaud, one of the most distinguished anthropophagites of all times, had already synthesized in a lapidary formula: "Je est un autre."

In conclusion I will provide only one example. In 1549, Joachim du Bellay published The Defense and Illustration of the French Language. He faced the difficult task of affirming the dignity of the French language when compared to Classical literatures and languages. As a fine strategist, du Bellay resorted to the history of Rome in order to prove that French language could convey thoughts as well as Latin. According to him, Romans had improved their language by "imitating the best Greek authors, transforming themselves into them, devouring them; and, after having well digested them, converting them into blood and nourishment". ${ }^{38}$ Sheer anthropophagy, as certainly Oswald de Andrade would have considered! After all, in the sixteenth century the French language was in an asymmetrical position regarding Greek and Latin, which were seen as the natural vehicles for artistic and philosophic expression, exactly as Brazilian artists, writers, and intellectuals were in the 1920s and to an extent Latin American authors and artists still are.

\footnotetext{
${ }^{34}$ On that issue, see Bendito Nunes. "O retorno à antropofagia.” Oswald canibal. São Paulo: Perspectiva, 1979, pp. 51-57.

${ }^{35}$ Peggy Reeves Sanday. Divine Hunger. Cannibalism as a Cultural System. Cambridge: Cambridge University Press, 1986, p. 3.

36 “A antropofagia ritual é assinalada por Homero entre os gregos (...). Na expressão de Colombo, comian los hombres. Não o faziam, porém, por gula ou fome. Tratava-se de um rito que, encontrado também nas outras partes do globo, dá a idéia de exprimir um modo de pensar, uma visão do mundo, que caracterizou certa fase primitiva de toda a humanidade". Oswald de Andrade. A crise da filosofia messiânica. A utopia antropofágica. São Paulo: Editora O Globo, 1990, p. 101.

${ }^{37}$ The anthropologist Carlos Fausto has considered Oswald de Andrade's metaphorical appropriation of the Tupi-guarani's ritual as fairly adequate: “As a metaphor anthropophagy seems to reveal a deep understanding of cannibalism as a practical and conceptual operation." Carlos Fausto. "Cinco séculos de carne de vaca. Antropofagia literal e antropofagia literária.” João Cezar de Castro Rocha and Jorge Ruffinelli (Eds.). Anthropophagy Today? Stanford University, 2000, p. 76.

${ }^{38}$ Joachim du Bellay. The Defense and Illustration of the French Language. London: J. M. Dent and Sons, 1939 , p. 37.
}

Rev. Bras. Lit. Comp. Niterói, v. 22, n. 41, pp. 15-26, set. /dez. 2020

https://doi.org/10.1590/2596-304X20202241jccr 
I may now return to the exhibitions curated by Paulo Herkenhoff and Jorge Schwartz. Their efforts help us to overcome the paradox both of a national and a regional definition of anthropophagy. Indeed, they have focused on its cultural procedure of appropriation of the other and not on a supposed national origin. The case of Schwartz's curatorship is exemplary: as an interpretive tool, anthropophagy may help to define a national circumstance, but it does not mean that we have to define anthropophagy nationally. In this broader context, the Brazilian dilemma ceases to be simply the traumatic mark of a given history-though it remains as such - and may become a laboratory for the non-hegemonic condition. Let's be done with the error of exceptionalism once and for all. ${ }^{39}$

Last but not least, if someone asks me what will be left to Brazilianists and LatinAmericanists if we "de-nationalize" and "de-regionalize" anthropophagy, my answer is simple: the taste not of a man but of the whole world.

\section{WORKS CITED:}

COLUMBUS, Christopher. Textos y documentos completos. Relaciones de viajes, cartas y memoriales. Consuelo Varela, ed., prólogo y notas. Madrid: Alianza, 1982.

DRAKULIC, Slavenka. The Taste of a Man. London: Abacus, 1998.

LARRETA, Enrique. La Naranja. Buenos Aires: Espasa-Calpe, 1947.

NABUCO, Joaquim. Minha Formação. Rio de Janeiro: Topbooks, 1999.

PRADO, J. F. de Almeida and SILVA, Maria Beatriz Nizza da (Eds.). Pero Vaz de Caminha. Carta do achamento do Brasil. Rio de Janeiro: Agir, 1998.

ROCHA, João Cezar de Castro. Shakespearean Cultures. Latin America and the Challenges of Mimesis in Non-Hegemonic Circumstances. East Lansing: Michigan State University Press, 2019.

(Ed.). Brazil 2001: A Revisionary History of Brazilian Literature and Culture.

Dartmouth, MA: Center for Portuguese Studies and Culture, 2001. and Jorge Ruffinelli (Eds.). Anthropophagy Today? Stanford University, 2000.

SANDAY, Peggy Reeves. Divine Hunger. Cannibalism as a Cultural System. Cambridge:

Cambridge University Press, 1986.

VELOSO, Caetano. Verdade tropical. São Paulo: Companhia das Letras, 1997

João Cezar de Castro Rocha is Full Professor of Comparative Literature at the State University of Rio de Janeiro and a researcher at the National Council for Scientific and Technological Development - CNPq. For further information see http://lattes.cnpq.br/2996791931732673

Submetido em 05/05/2020

Aprovado em 23/06/2020

\footnotetext{
${ }^{39}$ Here I might recall Joshua Lund's essay, "Barbarian Theorizing and the Limits of Latin American Exceptionalism," Cultural Critique 47 (2001): 54-90.
} 